\title{
SPECTROPHOTOMETRIC ANALYSIS OF CEFEPIME THROUGH ITS Hg(I) COMPLEX
}

\author{
Nawal A. El-Rabbat ${ }^{1}$, Hanaa M. Abdel-Wadood ${ }^{1}$, Mohammed Sayed ${ }^{2}$ and Heba S. Mousa ${ }^{3}$ \\ ${ }^{1}$ Department of Pharmaceutical Analytical Chemistry, Faculty of Pharmacy, Assiut University, \\ Assiut, Egypt \\ ${ }^{2}$ Department of Food Hygiene, Faculty of Veterinary Medicine, Assiut University, Assiut, \\ Egypt \\ ${ }^{3}$ Drug Research Center, Assiut University, Assiut, Egypt
}

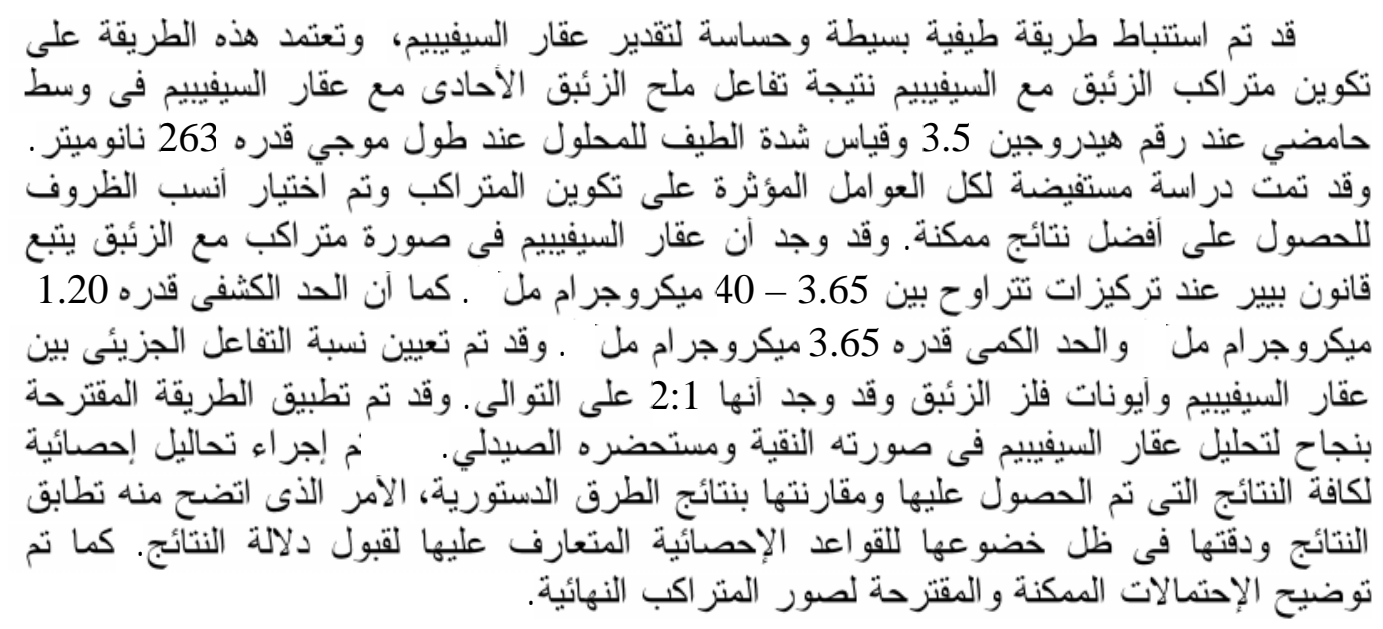

A spectrophotometric procedure was developed for determination of cefepime depending on the complexation of the drug with $\mathrm{Hg}_{2}\left(\mathrm{NO}_{3}\right)_{2}$ in acid medium (pH 3.5) and measuring the absorbance at $263 \mathrm{~nm}$. Different variables affecting the reaction were studied and optimized. Under the optimized conditions, linear relationship with good correlation coefficient (0.999)

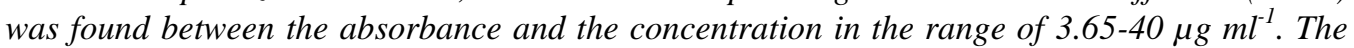
limits of detection and quantitation were 1.20 and $3.65 \mu \mathrm{g} \mathrm{ml}^{-1}$ respectively. The stoichiometry of the reaction was studied using Yoe and Jones method and was found to be 1:2 ratio for cefepime : $\mathrm{Hg}(\mathrm{I})$. The method was successfully applied for determination of cefepime in its vial with average percentage recovery of $98.95 \pm 1.079$. The results were favorably compared with those of reference method. The IR study of the formed complex was done and different probabilities of the formed complexes were suggested.

\section{INTRODUCTION}

Cefepime,(6R,7R,Z)-7-(2-(2-aminothiazol4-yl)-2-(methoxyimino)acetamido)-3-((1methylpyrrolidinium-1-yl)methyl)-8-oxo-5thia-1-aza-bicyclo[4.2.0] oct-2-ene-2carboxylate, (Fig. 1), is a new injectable fourthgeneration cephalosporin ${ }^{1}$.

Like other fourth generation cephalosporins, cefepime demonstrates good activity against gram-negative organisms such as Pseudomonas aeruginosa and gram-positive organisms such as Staphylococcus aureus ${ }^{2}$. It is indicated for respiratory tract infections, skin and soft tissue infections, urinary tract infections and febrile neutropenia ${ }^{2 \& 3}$.<smiles></smiles>

Fig. 1: Structure of cefepime.

Quantitative analytical methods for the determination of cefepime in biological fluids 
have been developed using several techniques, including electrochemical ${ }^{4 \& 5}$, micellar electrokinetic chromatography ${ }^{6 \& 7}$, HPLC with UV detection ${ }^{8-25}$ and HPLC with MS detection $^{26 \& 27}$. Although a variety of analytical techniques exist, many of these techniques lack the enough sensitivity and selectivity which enables the determination of small concentrations of cefepime in complex matrices in which it is typically found ${ }^{8-13 \& 17-21}$. Others offer the required sensitivity and selectivity for the determination of cefepime in biological fluids ${ }^{26 \& 27}$; however, their sophisticated instrumentation, high analytical cost and the need for technical experience limit their use in quality-control laboratories for determination of cefepime in its pharmaceutical dosage form. Therefore only few methods offer the inherent sensitivity and selectivity needed for determination of cefepime in biological fluids. Among which, is our recent paper for HPLC determination of cefepime in plasma and milk $^{24}$.

The analytical techniques reported for the determination of cefepime in its pharmaceutical dosage form include; HPLC ${ }^{1 \& 28-32}$, HPTLC ${ }^{33}$, electrochemical ${ }^{34}$, capillary electrophoresis ${ }^{35 \& 36}$ and spectrophotometry ${ }^{37-45}$. The chromatographic, electrochemical and electrophoretic methods use dedicated and/or expensive instruments that are not available in most quality-control laboratories. Therefore in general, spectrophotometry is considered the most convenient analytical technique because of its inherent simplicity, low cost and wide availability in most quality-control laboratories. However, most of the spectrophotometric methods reported for the determination of cefepime in its pharmaceutical formulation are associated with some drawbacks such as decreased selectivity due to measurement in the ultraviolet region ${ }^{37}$ and/or decreased simplicity of the assay procedure (e.g. laborious extraction steps in ion-pair formation-based methods ${ }^{38}$. For these reasons, it was considered worthwhile to develop new, simple and selective spectrophotometric procedure for the determination of cefepime.

There are no data on the complexation of cefepime with any metal ion in the literature and the reaction between cefepime with any metal ion has not been investigated yet. Therefore, the present study was devoted to explore the complexation ability of cefepime with different metal ions for the development of selective and sensitive spectrophotometric method for the determination of cefepime.

\section{EXPERIMENTAL}

\section{Instruments}

UV-1601

PC,

UV-Visible

spectrophotometer (Shimadzu, Japan) with 0.1 $\mathrm{cm}$ quartz cells. Ultrasonic cleaner (ColeParmer, Chicago, USA). pH meter, model 3305 (Jenway, London, UK). Shimadzu IR-470 infrared spectrometer (Kyoto, Japan). MLW type thermostatically controlled water bath (Germany).

\section{Materials}

Cefepime hydrochloride (Bristol-Myers Squibb Co., Cairo, Egypt). L-arginine (BDH, Poole, UK). Maxipime ${ }^{\circledR}$ vial, 0.5 g (BristolMyers Squibb Co., Cairo, Egypt) (containing $0.5 \mathrm{~g}$ cefepime and $0.36 \mathrm{~g}$ L-arginine). Antimony chloride, cobalt chloride, stannous chloride, zinc sulfate, ferrous sulfate, copper sulfate, ferric chloride, magnesium chloride, barium chloride, cadmium sulfate, lead nitrate, aluminum sulfate, chromium chloride, manganese sulfate, mercuric acetate, mercurous nitrate and silver nitrate. All metal salts were of analytical grade reagents (Prolabo Chemicals, Cairo, Egypt).

\section{Reagents and standard solutions}

Analytical grade acetonitrile, dioxan, dimethylformamide (DMF), dimethylsulfoxide (DMSO), ethanol, methanol and n-propanol were used throughout the investigation. Aqueous solution $\left(8 \times 10^{-4} \mathrm{M}\right)$ was prepared from each metal salt in double distilled water. Buffer solutions: Acetate buffer (acetic acid and sodium acetate) were prepared in freshly double distilled water of $\mathrm{pH}$ range $2-6^{1}$. The solutions were refrigerated in light protected flasks and used only for one week. Double distilled water was used for preparing solutions.

\section{Procedures}

Preparation of standard solutions: An accurately weighed amount of cefepime (40 $\mathrm{mg}$ ) was transferred into a $100 \mathrm{ml}$ volumetric flask, dissolved in about $60 \mathrm{ml}$ of double 
distilled water and then completed to the mark with the same solvent. Working standard solutions were prepared daily from the stock solution by serial dilutions with water to contain 20- $400 \mathrm{~g} \mathrm{ml}^{-1}$ cefepime.

General analytical procedure: Accurately measured $1 \mathrm{ml}$ aliquot of the working standard or sample solution of cefepime was transferred into a $10 \mathrm{ml}$ volumetric flask, followed by addition of $1 \mathrm{ml}$ of $\mathrm{Hg}_{2}\left(\mathrm{NO}_{3}\right)_{2}$ solution $(800 \mu \mathrm{g}$ $\mathrm{ml}^{-1}$ ) and the $\mathrm{pH}$ was adjusted to 3.5 using $1 \mathrm{ml}$ of acetate buffer solution $(0.1 \mathrm{M})$. The solution was shaken well, allowed to stand for $15 \mathrm{~min}$, completed to the mark with double distilled water and the absorbance was measured at 263 $\mathrm{nm}$ against a reagent blank prepared simultaneously.

Analysis of dosage form ${ }^{1}$ : The contents of 1 vial Maxpime ${ }^{\circledR}(0.5 \mathrm{~g})$ was transferred into a $100 \mathrm{ml}$ volumetric flask containing $30 \mathrm{ml}$ double distilled water. The contents of the flask were shaken well and completed to the mark with double distilled water. A suitable aliquot of the obtained solution was diluted quantitatively with the same solvent to obtain a concentration within the linearity range and suitable for determination of cefepime. The previous general assay procedure was then applied.

Procedure for determination of molar ratio by Yao and Jones method ${ }^{46}$ : Cefepime and $\mathrm{Hg}_{2}\left(\mathrm{NO}_{3}\right)_{2}$ solutions of equimolar concentrations $\left(4 \times 10^{-4} \mathrm{M}\right)$ were prepared. One $\mathrm{ml}$ aliquot of cefepime solution was transferred into a series of $10 \mathrm{ml}$ volumetric flasks followed by addition of $0.5,1.0,1.5,2,2.5,3$, 3.5 or $4 \mathrm{ml}$ of $\mathrm{Hg}_{2}\left(\mathrm{NO}_{3}\right)_{2}$ solution. The $\mathrm{pH}$ was adjusted to 3.5 using $1 \mathrm{ml}$ of acetate buffer solution to each flask. The solutions were allowed to stand for $15 \mathrm{~min}$ and completed with double distilled water to the mark. The UV-absorption intensities of the obtained mixtures were measured at $263 \mathrm{~nm}$.

Procedure for preparation of the formed complex for the IR investigation: A weight equivalent to $0.16 \mathrm{mM}$ of cefepime was dissolved in $5 \mathrm{ml}$ double distilled water then mixed with $5 \mathrm{ml}$ of $0.32 \mathrm{mM}$ of $\mathrm{Hg}_{2}\left(\mathrm{NO}_{3}\right)_{2}$ solution, the $\mathrm{pH}$ was adjusted to 3.5. The mixture was stirred and left for $15 \mathrm{~min}$ then the solution was evaporated till dryness under nitrogen stream in a $50-60^{\circ} \mathrm{C}$ water bath until crystalline solid was formed.

\section{RESULTS AND DISCUSSION}

The presence of donor atoms impeded in the structure of cefepime such as amino $\left(-\mathrm{NH}_{2}\right)$, imino $(=\mathrm{NH})$, heterocyclic nitrogen $(-\mathrm{N}=)$, carbonyl $(\mathrm{C}=\mathrm{O})$, carboxylate $(-\mathrm{COO})$, ether ($\mathrm{O}-)$ and oxime (-CONH) suggests that cefepime can act as a complexing agent. The UVspectrum of cefepime alone showed maximum absorbance at $257 \mathrm{~nm}$ (Fig. 2). Therefore, according to the change in the original UVabsorption spectrum of the drug, it was found that only 3 metal ions namely; $\mathrm{Hg}$ (I), $\mathrm{Hg}$ (II) and $\operatorname{Ag}(\mathrm{I})$ formed complexes with the drug aqueous solutions. It was found that at the same concentration of cefepime, $\mathrm{Hg}_{2}\left(\mathrm{NO}_{3}\right)_{2}$ showed higher intensity which means more sensitivity than $\mathrm{Hg}(\mathrm{OAC})_{2}$. On the other hand, $\mathrm{AgNO}_{3}$ increased the intensity of the UV-absorption spectra but did not show any new peaks.

So it was concluded that $\mathrm{Hg}_{2}\left(\mathrm{NO}_{3}\right)_{2}$ is the best metal salt to be used for complexation with cefepime and the following study will be on it to optimize the conditions of the reaction (Fig. 2).

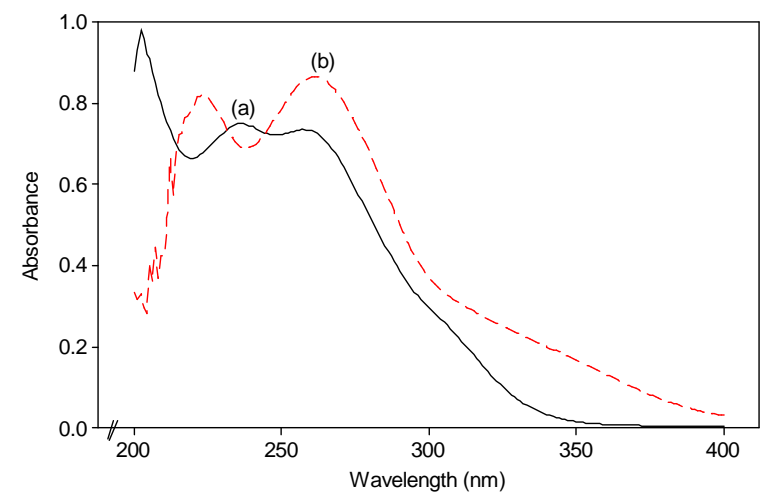

Fig. 2: Absorption spectra of:

(a) Cefepime $\left(4 \times 10^{-4} \mathrm{M}\right)$

(b) Cefepime $\left(4 \times 10^{-4} \mathrm{M}\right)$ with $\mathrm{Hg}_{2}\left(\mathrm{NO}_{3}\right)_{2}\left(8 \times 10^{-4} \mathrm{M}\right)$

\section{Optimization of the reaction conditions}

Experimental parameters including buffer type, $\mathrm{pH}$, buffer concentration, and mercurous ion concentration beside the linearity range were all comprehensively investigated in order to optimize the conditions of the assay procedure.

Effect of buffer type: Because of the formation of precipitate from $\mathrm{Hg}(\mathrm{I})$ ions with each of phosphate, Britton-Robinson and Teorell and Stenhagen buffer solutions, only acetate buffer can be used in this procedure. 
The effect of buffer $\mathrm{pH}$ value on the formation and stability of the complex was investigated using different acetate buffer solutions covering $\mathrm{pH}$ range of 2-6. It was found that, the absorption intensity of the formed complex increased with increasing $\mathrm{pH}$ of the solution and reached its maximum reading at $\mathrm{pH}$ 3-4 (Fig. 3). This can be explained by the suggestion that more acidic $\mathrm{pH}$ may suppress ionization of the carboxylic group leading to decreased rates of cefepime$\mathrm{Hg}(\mathrm{I})$ complexation. It should be noted that more alkaline $\mathrm{pH}$ may cause precipitation of $\mathrm{Hg}(\mathrm{I})$. Therefore, it was concluded that acetate buffer of pH 3.5 is the optimum and used for the subsequent work.

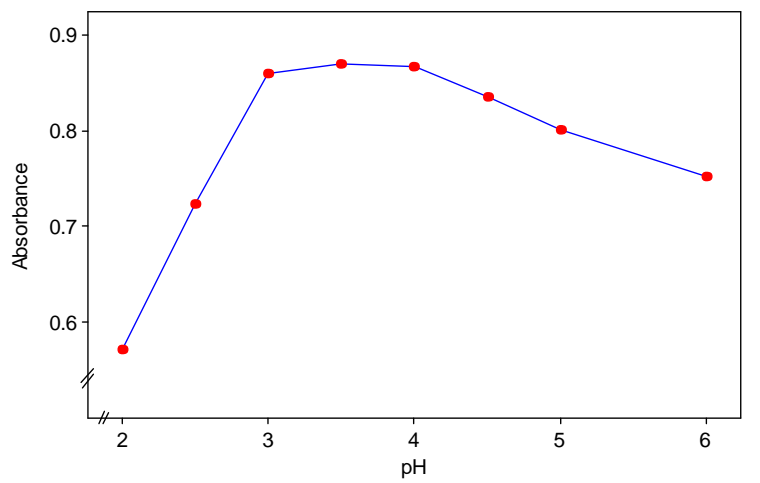

Fig. 3: Effect of $\mathrm{pH}$ on the absorption intensity of cefepime- $\mathrm{Hg}(\mathrm{I})$ complex at $263 \mathrm{~nm}$, cefepime $\left(22.8 \mu \mathrm{g} \mathrm{ml}^{-1}\right), \mathrm{Hg}_{2}\left(\mathrm{NO}_{3}\right)_{2}\left(80 \mu \mathrm{g} \mathrm{ml}^{-1}\right)$.

Effect of ionic strength of acetate buffer: Various ionic strengths of acetate buffer of $\mathrm{pH}$ $3.5(0.01-1.00 \mathrm{M})$ were tested and there were no significant differences observed in the UVabsorption intensity at the specified $\lambda_{\max }(263$ $\mathrm{nm})$. In the present investigation, $0.1 \mathrm{M}$ concentration of acetate buffer components was found to be optimum.

Effect of $\mathrm{Hg}_{2}\left(\mathrm{NO}_{3}\right)_{2}$ concentration: The influence of $\mathrm{Hg}_{2}\left(\mathrm{NO}_{3}\right)_{2}$ concentration was studied using $1 \mathrm{ml}$ of varying concentrations in the range of $100-1200 \mu \mathrm{g} \mathrm{ml}^{-1}$. It was found that the UV-absorption intensity of the formed complex increased with increasing metal salt concentration till the concentration reached about $600 \mu \mathrm{g} \mathrm{ml}^{-1}$ then became constant at higher concentration levels (up to $1200 \mu \mathrm{g} \mathrm{ml}^{-1}$ ) (Fig. 4). Therefore $1 \mathrm{ml}$ of $800 \mu \mathrm{g} \mathrm{ml}^{-1}$ solution of $\mathrm{Hg}_{2}\left(\mathrm{NO}_{3}\right)_{2}$ was optimum.

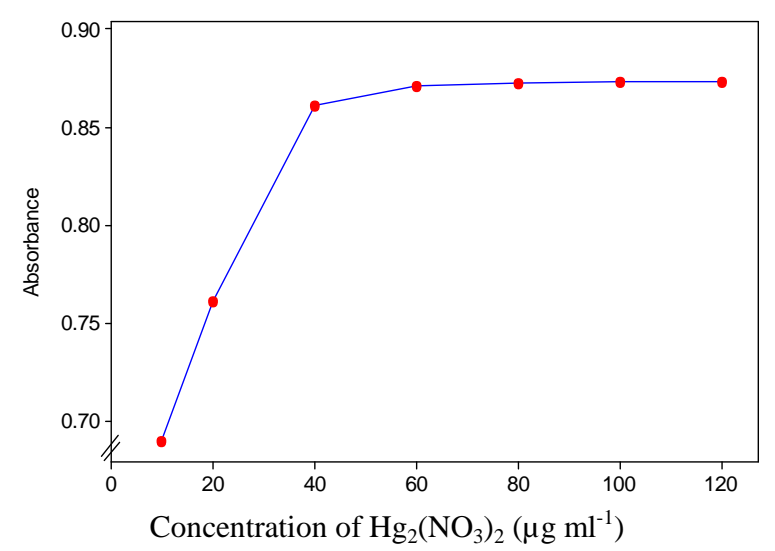

Fig. 4: Effect of $\mathrm{Hg}_{2}\left(\mathrm{NO}_{3}\right)_{2}$ concentration on the absorbance of cefepime-Hg(I) complex at $263 \mathrm{~nm}$, cefepime concentration; $22.8 \mu \mathrm{g} \mathrm{ml}^{-1}$ final concentration.

Effect of reaction time: The optimum reaction time was determined by following the absorption intensity before dilution with water at $5 \mathrm{~min}$ intervals. Figure 5 shows that the absorption intensity increased with time and maximum intensity reached after about $10 \mathrm{~min}$ then remained approximately constant up to 60 min. Therefore, measurements are recommended to be done in the period of $15-50$ min, after addition of the metal and buffer solutions.

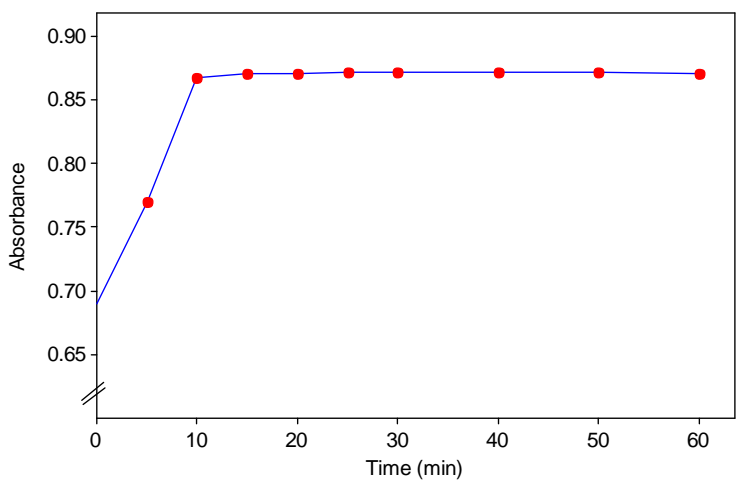

Fig. 5: Effect of time on the absorption intensity of $\mathrm{Hg}(\mathrm{I})$-cefepime complex at $263 \mathrm{~nm}$; cefepime $\left(22.8 \mu \mathrm{g} \mathrm{ml}^{-1}\right.$ final concentration), $\mathrm{Hg}_{2}\left(\mathrm{NO}_{3}\right)_{2}\left(80 \mu \mathrm{g} \mathrm{ml}^{-1}\right.$ final concentration).

Effect of diluting solvent: The effect of various solvents on the absorption intensity of the formed complex was studied. From the results listed in table 1 , it is noticed that the UV-absorption intensity was maximized by using water as diluting solvent. 
Table 1: Effect of solvent type on the absorption intensity of cefepime- $\mathrm{Hg}(\mathrm{I})$ complex.

\begin{tabular}{||l|c|}
\hline \multicolumn{1}{|c|}{ Solvent } & Absorbance $^{*}$ \\
\hline 1- Water & 0.871 \\
\hline 2- n- Propanol & 0.625 \\
\hline 3- Ethanol & 0.578 \\
\hline 4- Methanol & 0.552 \\
\hline 5- DMSO & 0.550 \\
\hline 6- DMF & 0.502 \\
\hline 7- Acetonitrile & 0.357 \\
\hline 8- Dioxane & 0.188 \\
\hline
\end{tabular}

"Cefepime concentration is $22.8 \mu \mathrm{g} / \mathrm{ml}$, at $263 \mathrm{~nm}$. N.B. Each result is an average of 3 separate determinations.

Stability time of the formed complex: It was found that the intensity of the absorbance remained stable for at least $60 \mathrm{~min}$, which indicated that the complex was stable for at least $60 \mathrm{~min}$.

\section{Determination of the molar ratio}

Yoe and Jones method ${ }^{46}$ was used to study the molar ratio of the formed complex. The method revealed a 1:2 ratio for cefepime : $\mathrm{Hg}(\mathrm{I})$ complex (Fig. 6).

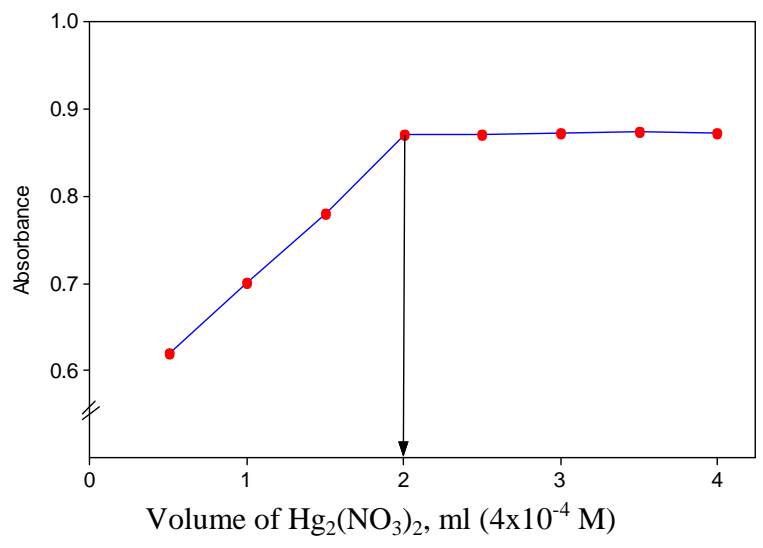

Fig. 6: Determination of molar reactivity of cefepime- $\mathrm{Hg}(\mathrm{I})$ complex using Yoe and Jones method, cefepime $1 \mathrm{ml}\left(4 \times 10^{-4} \mathrm{M}\right)$.

\section{IR study}

Crystalline solid of cefepime- $\mathrm{Hg}(\mathrm{I})$ complex was isolated. The IR spectra of the isolated solid drug and solid complex were compared. The IR spectra are shown in figure 7. The IR spectrum of cefepime (Fig. 7a) showed a strong sharp band at $1765 \mathrm{~cm}^{-1}$ which is corresponding to the stretching vibration of $\mathrm{C}=\mathrm{O}$ of the $\beta$ lactam ring and another 2 bands at $1642 \mathrm{~cm}^{-1}$ and at $1620 \mathrm{~cm}^{-1}$ which are corresponding to the stretching vibrations of $\mathrm{C}=\mathrm{O}$ of the amide group and $\mathrm{C}=\mathrm{O}$ of the free carboxylic group respectively. In addition a broad band extending from $2900 \mathrm{~cm}^{-1}$ to 3300 $\mathrm{cm}^{-1}$ indicating the presence of carboxylic $\mathrm{OH}$ group. After formation of the complex with $\mathrm{Hg}(\mathrm{I})$, the band corresponding to the $\mathrm{C}=\mathrm{O}$ of the free carboxylic group and that corresponding to the carboxylic $\mathrm{OH}$ group disappeared (Fig. 7b) and instead a broad band at $1609 \mathrm{~cm}^{-1}$ is recorded. This band is corresponding to the stretching vibrations of $\mathrm{C}=\mathrm{O}$ of the carboxylate group. Also the sharp band at $1642 \mathrm{~cm}^{-1}$ which is corresponding to the stretching vibration of $\mathrm{C}=\mathrm{O}$ of the amide group also disappeared and a broader one at $1640 \mathrm{~cm}^{-1}$ is recorded. Table 2 shows the main IR absorption transitions of cefepime and those of the complex.

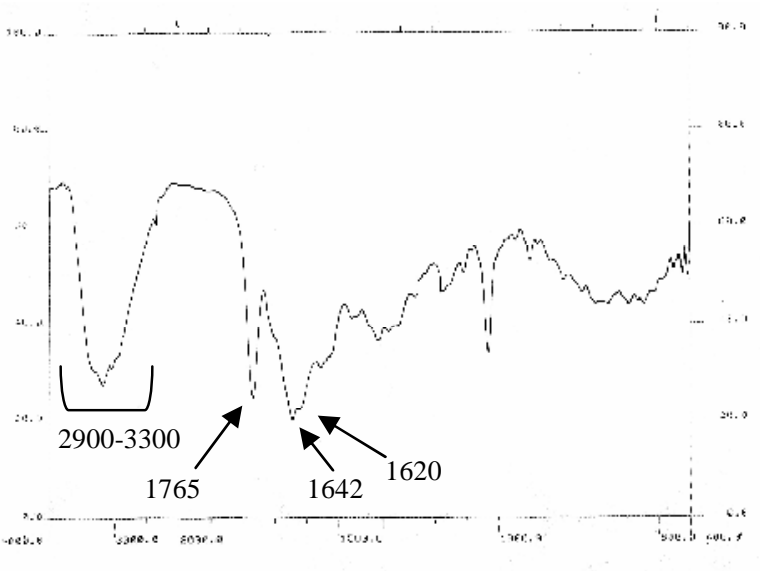

(a)

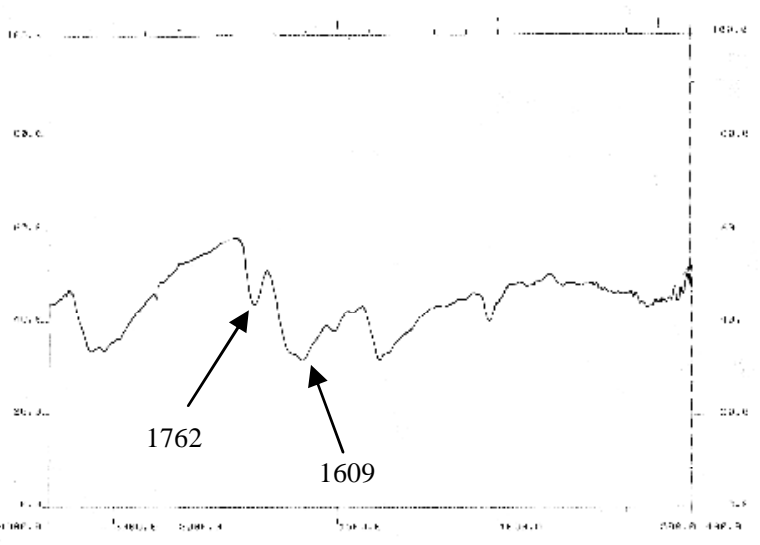

(b)

Fig. 7: IR spectra of:

(a) cefepime

(b) cefepime- $\mathrm{Hg}(\mathrm{I})$ complex. 
Table 2: Assignments for the main IR absorption transition bands of cefepime and those of cefepime$\mathrm{Hg}(\mathrm{I})$ complex.

\begin{tabular}{||l|c|c||}
\hline \multirow{2}{*}{ Main bands } & \multicolumn{2}{|c|}{ Frequency $\left(\mathrm{cm}^{-1}\right)$} \\
\cline { 2 - 3 } & Cefepime & Cefepime-Hg(I) complex \\
\hline OH stretching & $2900-3300$ & Disappeared \\
\hline$\beta$ lactam $\mathrm{C}=\mathrm{O}$ stretching & 1765 & 1762 \\
\hline Amide $\mathrm{C}=\mathrm{O}$ stretching & 1642 & $\begin{array}{c}\text { Disappeared and instead a broader band at } \\
\text { a } 1640 \text { of the imide appeared }\end{array}$ \\
\hline Carboxylic $\mathrm{C}=\mathrm{O}$ stretching & 1620 & 1609 of the carboxylate \\
\hline
\end{tabular}

\section{Analytical method validation}

The developed procedure was fully validated according to International Conference on Harmonization $(\mathrm{ICH})^{47}$ guidelines and complied with $\mathrm{USP}^{1}$ validation guidelines. The objective of the validation of an analytical procedure is to demonstrate that it is suitable for its intended purpose. The performance and the statistical data of the proposed method are shown in table 3.

Linearity: Under the previously mentioned experimental conditions, the calibration curve of cefepime- $\mathrm{Hg}(\mathrm{I})$ complex was constructed by plotting the UV-absorbance versus the drug concentration. Beer's law was found to be obeyed in the concentration range 3.65-40 $\mu \mathrm{g}$ $\mathrm{ml}^{-1}, \mathrm{r}^{2}=0.9981$ (Table 3).

Limit of detection (LOD) and limit of quantitation (LOQ): The detection and quantitation limits were 1.20 and $3.65 \mathrm{~g} \mathrm{ml}^{-1}$, respectively (Table 3 ).

Table 3: The performance and the statistical data of the proposed spectrophotometric method.

\begin{tabular}{|l|c|}
\hline \multicolumn{1}{|c|}{ Parameter } & Cefepime \\
\hline$\lambda_{\max }(\mathrm{nm})$ & 263 \\
\hline Working range & $3.65-40 \mathrm{~g} / \mathrm{ml}$ \\
\hline Regression equation & $\mathrm{Y}=-0.009+0.036 \mathrm{X}$ \\
\hline $\mathrm{R}$ & 0.9990 \\
\hline $\mathrm{r}^{2}$ & 0.9981 \\
\hline $\mathrm{S}_{\mathrm{a}}$ & 0.013 \\
\hline $\mathrm{S}_{\mathrm{b}}$ & $5.94 \times 10^{-4}$ \\
\hline LOQ & $3.65 \mathrm{~g} / \mathrm{ml}$ \\
\hline LOD & $1.20 \mathrm{~g} / \mathrm{ml}$ \\
\hline
\end{tabular}

Precision and accuracy: The precision of the proposed method was checked by replicate analysis of 6 separate solutions of the working standard at 3 concentration levels. The repeatability of the assay was found to be within $0.928-1.454 \%(n=6)$ at $3.7,28,40 \mathrm{~g}$ $\mathrm{ml}^{-1}$ (Table 4). It is clear from the results that the relative standard deviation\% (coefficient of variation) for all concentration levels is less than $2 \%$ indicating excellent precision of the proposed method.

Table 4: Precision data for cefepime using the proposed method.

\begin{tabular}{|l|c|c|c|}
\hline \multirow{2}{*}{ Parameter } & \multicolumn{3}{|c|}{ Cefepime concentration } \\
\cline { 2 - 4 } & 3.7 & 28 & 40 \\
\hline Mean \% Recovery & 100.19 & 100.48 & 99.61 \\
\hline \pm SD & 1.454 & 1.130 & 0.928 \\
\hline \% RSD & 1.451 & 1.124 & 0.931 \\
\hline
\end{tabular}

Accuracy of the proposed procedure was checked by applying the proposed method for the assay of the studied drug in its vial and comparing the obtained results with those of the official method ${ }^{1}$.

Selectivity: The selectivity of an analytical method is its ability to measure accurately an analyte in the presence of interference that may be expected to be present in the sample matrix. The selectivity of the method was checked by studying the interference from other compounds that are present in the formulation. It was found that, there was no interference from L-arginine which is co-formulated with cefepime in the vial, as shown from the excellent recoveries obtained when analyzing cefepime in presence of L-arginine (Table 5). This is because L-arginine has no UVabsorbance at $\lambda_{\max }$ of cefepime- $\mathrm{Hg}(\mathrm{I})$ complex, at $263 \mathrm{~nm}^{37}$ and it was found that it did not form a complex with $\mathrm{Hg}(\mathrm{I})$ ions. Also it was found that N-methyl pyrrolidine (NMP), which 
is the main degradation product of cefepime ${ }^{3}$, also has no UV-absorbance at $\lambda_{\max }$ of cefepime$\mathrm{Hg}(\mathrm{I})$ complex, at $263 \mathrm{~nm}^{48}$. These facts indicate proper selectivity of the method for determination of cefepime in raw material and in its dosage form. So the method is considered selective.

Robustness: The robustness of an analytical procedure is a measure of its capacity to remain unaffected by small but deliberate variation in method parameters and provides an indication of its reliability during normal usage. It was examined by evaluating the influence of small variation of method variables including $\mathrm{pH}$ of the buffer, ionic strength of the buffer, $\mathrm{Hg}_{2}\left(\mathrm{NO}_{3}\right)_{2}$ concentration and reaction time on the method suitability and sensitivity. It was found that none of these variables significantly affect the method (Table 5). This provides an indication of the reliability of the proposed method during normal usage and so the proposed spectrophotometric method is considered robust.

Table 5: Robustness of the proposed spectrophotometric method.

\begin{tabular}{|c|c|}
\hline Variation & $\begin{array}{c}\% \text { Recovery }^{*} \\
\pm \mathrm{SD}\end{array}$ \\
\hline No variation ${ }^{* *}$ & $99.79 \pm 0.68$ \\
\hline \multicolumn{2}{|l|}{ 1- $\mathrm{pH}$ of the buffer } \\
\hline pH 3.3 & $98.86 \pm 0.67$ \\
\hline $\mathrm{pH} 3.7$ & $99.91 \pm 0.82$ \\
\hline \multicolumn{2}{|l|}{ 2- Ionic strength of the buffer } \\
\hline $0.09 \mathrm{M}$ & $98.90 \pm 0.46$ \\
\hline $0.11 \mathrm{M}$ & $99.81 \pm 0.56$ \\
\hline \multicolumn{2}{|l|}{ 3- $\mathrm{Hg}_{2}\left(\mathrm{NO}_{3}\right)_{2}$ concentration } \\
\hline $78 \mu \mathrm{g} \mathrm{ml}^{-1}$ & $99.34 \pm 0.50$ \\
\hline $82 \mu \mathrm{g} \mathrm{ml}^{-1}$ & $100.10 \pm 0.45$ \\
\hline \multicolumn{2}{|l|}{ 4- Reaction time } \\
\hline $14 \min$ & $99.60 \pm 0.54$ \\
\hline $16 \mathrm{~min}$ & $100.46 \pm 0.56$ \\
\hline
\end{tabular}

* Average of 3 determinations.

** No variations in the assay condition of the proposed method.

\section{Application of the proposed method to the analysis of cefepime in its vial}

The complexation ability of $\mathrm{Hg}(\mathrm{I})$ was applied for analysis of cefepime in its vial and the proposed method was successfully applied. The average $\%$ recoveries of different concentrations were based on average of 6 replicate determinations and the results obtained were validated by comparison with USP 31 method $^{1}$ by means of $\mathrm{t}$-and F-tests at $95 \%$ confidence level. No significant difference was found between the results obtained by both methods indicating good accuracy and precision (Table 6).

Table 6: Assay of cefepime in commercial vial using the proposed and the official methods.

\begin{tabular}{||l|c|c||}
\hline \multirow{2}{*}{\multicolumn{1}{|c|}{ Parameters }} & \multicolumn{2}{c|}{ Maxipime 500 mg } \\
\cline { 2 - 3 } & Proposed & Official $^{29}$ \\
\hline Mean \% Recovery & 98.95 & 99.92 \\
\hline \pm SD & 1.079 & 0.958 \\
\hline Student's t-test & \\
\hline $\begin{array}{l}\text { Variance ratio F- } \\
\text { test }^{\mathrm{c}}\end{array}$ & 1.646 & \\
\hline \hline
\end{tabular}

aproduct of Bristol-Myers Squibb Egypt.

${ }^{\mathrm{b}} \mathrm{n}=6$.

${ }^{\mathrm{c}}$ Theoretical values at $95 \%$ confidence limit;

$$
\mathrm{t}=2.228 \quad \mathrm{~F}=5.050 \text {. }
$$

The assay results obtained by the proposed procedure were unaffected by the presence of L-arginine as shown by the excellent recoveries obtained when analyzing cefepime in presence of L-arginine in the vial. This is because Larginine has no UV-absorbance at $\lambda_{\max }$ of cefepime, at $263 \mathrm{~nm}^{37}$ and it did not form a complex with $\mathrm{Hg}(\mathrm{I})$ ions. So the proposed assay can be used for quantitation and routine quality control analysis of cefepime in its dosage form. This fact indicates proper selectivity of the method for determination of cefepime- $\mathrm{Hg}(\mathrm{I})$ complex in raw material and in its dosage form.

\section{Reaction mechanism}

According to the previous studies regarding the $\mathrm{pK}_{\mathrm{a}}$ values of cefepime ${ }^{37}$, at $\mathrm{pH}<$ 4 , cefepime exists as a zwitterions and this was attributed to the presence of the quaternary nitrogen atom which interacts with the 2carboxylic anion forming zwitterions. So occurrence of the reaction in acid medium is logic.

From the IR spectra of the drug and the complex, we can suggest a mechanism of the complexation of cefepime with $\mathrm{Hg}(\mathrm{I})$ as follows. For the first metal cation, the 
complexation may occur through salt formation of the metal cation with the 2-carboxylate group of the drug and coordination either with the 8-carbonyl group to form a 7-membered ring (Fig. 8a) or with the lone pair of electrons of the 1-nitrogen of the $\beta$ lactam ring to form a 5 -membered ring (Fig. 8b,c). For the second metal cation, it is suggested that keto-enol tautomerism has been occurred in the 7-amino group of the drug, resulting in a free $\mathrm{OH}$ group, and complexation may occur through replacement of the hydrogen atom forming a bond with the metal cation and coordination either with the lone pair of electrons of the nitrogen of the oxime at the side chain to form a 5-membered ring (Fig. 8a,c) or with the 8carbonyl group to form a 7 -membered ring (Fig. 8b). Therefore there are 3 probabilities for the formed cefepime-Hg(I) complex as shown in figure 8 .

$\mathbf{a}$

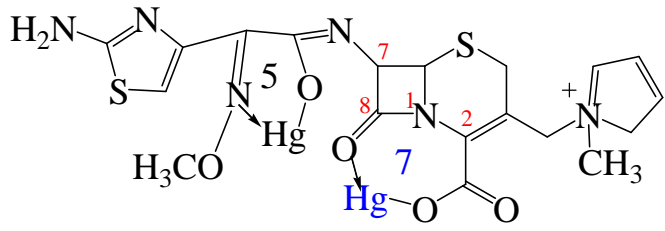

b

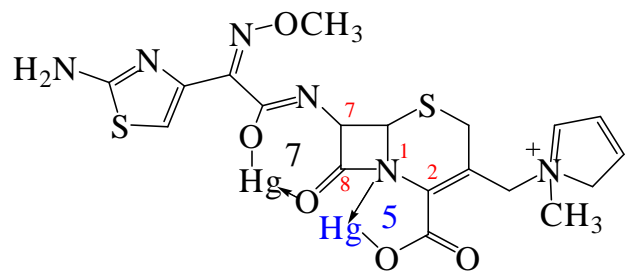

c

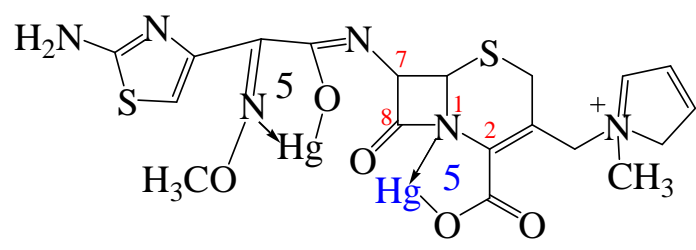

Fig. 8: The suggested probabilities of the formed cefepime- $\mathrm{Hg}(\mathrm{I})$ complex (a, b or c).

\section{Conclusion}

The present study described, for the first time, the complexation of cefepime with $\mathrm{Hg}(\mathrm{I})$ ions for the development of selective, sensitive and accurate spectrophotometric. The developed method is simple, rapid, accurate and reliable for determination of cefepime in its pharmaceutical dosage form without interference from common excipients. The proposed method is of great value in quality- control determination of cefepime because of its improved simplicity and sensitivity, low cost and freedom of dependence on expensive instruments and/or critical analytical reagents. All these facts and the inherent stability of the formed complex encouraged our team to apply this complexation reaction for the development of a precolumn derivatization HPLC method for the analysis of cefepime in bulk, its vial and biological fluid.

\section{REFERENCES}

1- USP, The United States Pharmacopeia 31, The National Formulary 26, Rockville, US Pharmacopeial Convention Inc., 2008, pp. 813, 1669, 2256-2258.

2- S. C. Sweetman, "In Martindale, The Complete Drug Reference", $33^{\text {rd }}$ ed., The Pharmaceutical press, London, 2002, pp. 165-166.

3- D. W. Sifton, "In Physicians' Desk Reference", $56^{\text {th }}$ ed., Montvale, New Jersey, Medical Economics Company Inc., 2002, pp. 1285-1289.

4- F. J. J. Palacios, M. C. Mochon, J. C. J. Sanchez and J. H. Carranza, "Electrochemical reduction of cefepime at the mercury electrode", Electroanalysis, 12, 296-300 (2000).

5- F. J. J. Palacios, M. C. Mochon, J. C. J. Sanchez and J. H. Carranza, "Adsorptive stripping voltammetric determination of cefepime at the mercury electrode in human urine and cerebrospinal fluid and differential pulse polarographic determination in serum", J. Pharm. Sci., 92, 1854-1859 (2003).

6- S. H. Tseng, Y. H. Yang, Y. R. Chen and S. H. Chen, "Determination of cefepime in plasma and cerebrospinal fluid by micellar electrokinetic chromatography with direct sample injection", Electrophoresis, 25, 1641-1647 (2004).

7- Y. H. Yang, W. Y. Wu, H. H. Yeh and S. H. Chen, "Simultaneous determination of cefepime and vancomycin in plasma and cerebrospinal fluid by MEKC with direct sample injection and application for bacterial meningitis", ibid., 28, 1788-1797 (2007).

8- R. H. Barbhaiya, S. T. Forgue, W. C. Shyu, E. A. Papp and K. A. Pittman, 
"High pressure liquid chromatographic analysis of BMY-28142 in plasma and urine", Antimicrob. Agents Chemother., 31, 55-59 (1987).

9- H. Elkhaili, L. Linger, H. Monteil and F. Jehl, "High performance liquid chromatographic assay for cefepime in serum", J. Chromatogr. B, 690, 181-188 (1997).

10- B. Calahorra, M. A. Campanero, B. Sadaba and J. R. Azanza, "High performance liquid chromatographic determination of cefepime in human plasma", Biomed. Chromatogr., 13, $272-$ 275 (1999).

11- D. Breilh, C. Lavallee, A. Fratta, D. Ducint, P. Cony- Makhoul and M. C. Saux, "Determination of cefepime and cefpirome in human serum by highperformance liquid chromatography using an ultrafiltration for antibiotics serum extraction", J. Chromatogr. B, 734, 121127 (1999).

12- I. N. Valassis, M. Parissi-Poulou and P. Macheras, "Quantitative determination of cefepime in plasma and vitreous fluid by high-performance liquid chromatography", ibid., 721, 249-255 (1999).

13- N. Cherti, J. M. Kinowski, J. Y. Lefrant and F. Bressolle, "High-performance liquid chromatographic determination of cefepime in human plasma and in urine and dialysis fluid using a columnswitching technique", ibid., 754, 377-386 (2001).

14- Y. L. Chang, M. H. Chou, M. F. Lin, C. F. Chen and T. H. Tsai, "Determination and pharmacokinetic study of unbound cefepime in rat bile by liquid chromatography with on-line microdialysis", J. Chromatogr. A, 914, 77 82 (2001).

15- D. Bugnon, D. Giannoni, P. Majcherczyk, M. P. Glauser and P. Moreillon, "Pitfalls in cefepime titration from human plasma: Plasma- and temperature-related drug degradation in-vitro", Antimicrob. Agents Chemother., 46, 3654-3656 (2002).

16- J. A. O. Gonzalez, F. J. J. Palacios, M. C. Mochon and F. J. Barragan de la Rosa, "Simultaneous determination of cefepime and grepafloxacin in human urine by highperformance liquid chromatography", J.
Pharm. Biomed. Anal., 36, 117-123 (2004).

17- A. Isla, A. Arzuaga, J. Maynar, A. R. Gascon, M. A. Solinis, E. Corral and J. L. Pedraz, "Determination of ceftazidime and cefepime in plasma and dialysateultrafiltrate from patients undergoing continuous veno-venous hemodiafiltration by HPLC", ibid., 39, 996-1005 (2005).

18- F. J. J. Palacios, M. C. Mochon, J. C. J. Sanchez, M. A. B. Lopez and A. G. Perez, "Validation of an HPLC method for determination of cefepime (a fourthgeneration cephalosporin) determination in human serum, cerebrospinal fluid and urine pharmacokinetic profiles", Chromatographia, 62, 355-361 (2005).

19- K. J. V. Lopez, D. F. Bertoluci, K. M. Vicente, A. M. Dell' Aquilla and S. R. C. J. Santos, "Simultaneous determination of cefepime, vancomycin and imipenem in human plasma of burn patients by highperformance liquid chromatography", J. Chromatogr. B, 860, 241-245 (2007).

20- R. Denooz and C. Charlier, "Simultaneous determination of five $\beta$-lactam antibiotics (cefepim, ceftazidim, cefuroxim, meropenem and piperacillin) in human plasma by high-performance liquid chromatography with ultraviolet detection", ibid., 864, 161-167 (2008).

21- C. Farthing, D. Farthing, D. F. Brophy, T. Larus, L. Maynor, I. Fakhry and T. W. B. Gehr, "High-performance liquid chromatographic determination of cefepime and cefazolin in human plasma and dialysate", Chromatographia, 67, 365368 (2008).

22- E. Nemutlu, S. Kir, D. Katlan and M. S. Beksac, "Simultaneous multiresponse optimization of an HPLC method to separate seven cephalosporins in plasma and amniotic fluid application to validation and quantification of cefepime, cefixime and cefoperazone", Talanta, 80, 117-126 (2009).

23- M. R. Siddiqui, A. Tariq, K. D. Reddy, P. S. Negi, J. Yadav, A. Bhatnagar, M. Chaudhary and R. Singh, "High performance liquid chromatographic method for simultaneous determination of cefepime and sulbactam in pharmaceutical formulation (supime) and biological 
samples", Int. J. Pharmacol., 6, 271-277 (2010).

24- Nawal A. El-Rabbat, Hanaa M. AbdelWadood, M. Sayed and Heba S. Mousa, "High-performance liquid chromatographic determination and pharmacokinetic study of cefepime in goat plasma and milk after pre-column derivatization with $\mathrm{Hg}(\mathrm{I})$ ", J. Sep. Sci., 33, 2599-2609 (2010).

25- M. C. Verdier, O. Tribut, P. Tattevin, Y. Le Tulzo, C. Michelet and D. BentuéFerrer, "Simultaneous determination of 12 beta-lactam antibiotics in human plasma by high-performance liquid chromatography with UV detection application to therapeutic drug monitoring", Antimicrob. Agents Chemother., 55, 4873-4879 (2011).

26- T. Ohmori, A. Suzuki, T. Niwa, H. Ushikoshi, K. Shirai, S. Yoshida, S. Ogura and Y. Itoh, "Simultaneous determination of eight $\beta$-lactam antibiotics in human serum by liquid chromatography-tandem mass spectrometry", J. Chromatogr. B, 879, 1038-1042 (2011).

27- W. Bu, H. Sexton, X. Fan, P. Torres, P. Houston, I. Heyman and L. Liu, "The novel sensitive and high throughput determination of cefepime in mouse plasma by SCX-LC/MS/MS method following off-line microElution 96-well solid-phase extraction to support systemic antibiotic programs", ibid., 878, 16231628 (2010).

28- S. M. Rabouan-Guyon, A. F. Guet, P. Y. Courtois and D. M. C. Barthes, "Stability study of cefepime in different infusion solutions", Int. J. Pharm., 154, 185-190 (1997).

29- J. O. Fubara and R. E. Notari, "Influence of $\mathrm{pH}$, temperature and buffers on cefepime degradation kinetics and stability predictions in aqueous solutions", J. Pharm. Sci., 87, 1572-1576 (1998).

30- F. C. Maddox and J. T. Stewart, "HPLC determination of aqueous cefepime and metronidazole mixture", J. Liq. Chrom. \& Rel. Technol., 22, 2807-2813 (1999).

31- P. F. Sprauten, P. M. Beringer, S. G. Louie, T. W. Synold and M. A. Gill, "Stability and antibacterial activity of cefepime during continuous infusion", Antimicrob. Agents Chemother., 47, 1991-1994 (2003).

32- E. F. Elkady and S. S. Abbas, "Development and validation of a reversed-phase column liquid chromatographic method for the determination of five cephalosporins in pharmaceutical preparations", J. AOAC Int., 94, 1440-1446 (2011).

33- S. C. Dhanesar, "Quantitation of antibiotics by densitometry on a hydrocarbon-impregnated silica gel HPTLC plate, Part III: Quantitation and evaluation of cephalosporins", J. Planar Chromatogr. Mod. TLC, 12, 114-119 (1999).

34- S. A. Özkan, B. Uslu and P. Zuman, "Electrochemical reduction and oxidation of the antibiotic cefepime at a carbon electrode", Anal. Chim. Acta, 457, 265274 (2002).

35- H. Liu and V. B. Sunderland, "Validated method for simultaneous determination of cefepime and L-Arginine in cefepime for injection by capillary zone electrophoresis", J. Liq. Chromo \& Rel. Technol., 27, 3065-3076 (2004).

36- Y. R. Chen, S. J. Lin, Y. W. Chou, H. L. $\mathrm{Wu}$ and S. H. Chen, "Simultaneous determination of cefepime and L-Arginine by micellar electrokinetic chromatography and applications to commercial injections", J. Sep. Sci., 28, 2173-2179 (2005).

37- V. Rodenas, A. Parra, J. Garcia-Villanova and M. D. Gomez, "Simultaneous determination of cefepime and L-Arginine in injections by second-derivative spectrophtometry", J. Pharm. Biomed. Anal., 13, 1095-1099 (1995).

38- O. I. Abd El-Sattar, N. M. El-Abasawy, S. A. Abd El-Razeq, M. M. F. Ismail and N. S. Rashed, "Spectrophotometric determination of cefepime and cefprozil by three different methods", Saudi Pharm. J., 9, 186-192 (2001).

39- M. S. Elazazy, A. Shalaby, M. N. Elbalkiny and H. M. Khalil, "Spectrophotometric determination of cefepime hydrochloride, cefoperazone sodium, ceftazidime pentahydrate, cefuroxime sodium and etamsylate using 
ammonium molybdate", Scientia Pharmaceutica, 71, 211-228 (2003).

40- M. S. Elazazy, A. Shalaby, M. N. Elbalkiny and H. M. Khalil, "Spectrophotometric determination of acyclovir, cefepime hydrochloride, etamsylate and metoclopramide hydrochloride using 1,10-phenanthrolineFe(III) reagent", ibid., 72, 73-86 (2004).

41- D. G. Sankar, M. V. Krishna, D. V. S. P. Kumar and P. V. M. Latha, "1,10Phenanthroline as an analytical reagent for the estimation of cefepime and repaglinide", Asian J. Chem., 17, 13601362 (2005).

42- D. G. Sankar, P. V. M. Latha and M. V. Krishna, "Spectrophotometric determination of cefepime", ibid., 17, 2049-2051 (2005).

43- D. G. Sankar, S. K. Sumanth, A. K. M. Pawar and P. V. M. Latha, "Spectrophotometric determination of cefepime and ezetamibe", ibid., 18, 15261528 (2006).
44- S. A. Patel, N. M. Patel, M. M. Patel and S. K. Patel, "Spectrophotometric estimation of fourth generation cephalosporins cefepime and cefpirome in pharmaceutical dosage forms", J. Pharm. Res., 6, 155-157 (2007).

45- D. G. Sankar, B. D. Rao, P. V. M. Latha and M. V. Krishna, "Spectrophotometric Determination of ezetimibe and cefepime", Asian J. Chem., 19, 1613-1615 (2007).

46- J. A. Yoe and A. L. Jones, "Colorimetric determination of iron", Ind. Eng. Chem. Anal. ed., 16, 111-115 (1944).

47- Q2B, Topic, "Validation of Analytical Procedures Methodology, International Conference on Harmonization (ICH)", (2005).

48- G. Chen, G. Liu, F. Qin and Y. Wang, "A simple and sensitive GC method for determination of $\mathrm{N}$-methylpyrrolidine in cefepime and its preparation", J. Pharm. Biomed. Anal., 33, 797-801 (2003). 